Article

\title{
Antibacterial Efficacy of Commercially Available Essential Oils Tested Against Drug-Resistant Gram-Positive Pathogens
}

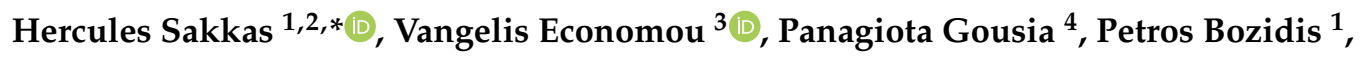 \\ Vasilios A. Sakkas ${ }^{5}$, Stefanos Petsios ${ }^{4}$, George Mpekoulis ${ }^{1}$, Afrodite Ilia ${ }^{1}$ and \\ Chrissanthy Papadopoulou 1,4 (iD) \\ 1 Microbiology Department, Faculty of Medicine, School of Health Sciences, University of Ioannina, \\ 45110 Ioannina, Greece; pbozidis@cc.uoi.gr (P.B.); bl01445@cc.uoi.gr (G.M.); bl01524@cc.uoi.gr (A.I.); \\ cpapadop@uoi.gr (C.P.) \\ 2 Clinical Microbiology Laboratory, University Hospital, 45110 Ioannina, Greece \\ 3 Laboratory of Hygiene of Foods of Animal Origin-Veterinary Public Health, School of Veterinary Medicine, \\ Faculty of Health Sciences, Aristotle University of Thessaloniki, 54124 Thessaloniki, Greece; \\ boikonom@vet.auth.gr \\ 4 Food Microbiology Group, Microbiology Department, Faculty of Medicine, School of Health Sciences, \\ University of Ioannina, 45110 Ioannina, Greece; pgousia@cc.uoi.gr (P.G.); spetsios@cc.uoi.gr (S.P.) \\ 5 Laboratory of Analytical Chemistry, Department of Chemistry, School of Sciences, University of Ioannina, \\ 45110 Ioannina, Greece; vsakkas@cc.uoi.gr \\ * Correspondence: isakkas@uoi.gr; Tel.: +30-265-100-7769
}

Received: 10 October 2018; Accepted: 7 November 2018; Published: 9 November 2018

check for updates

\begin{abstract}
The potential antibacterial activity of basil (Ocimum basilicum), chamomile (Matricaria chamomilla), origanum (Thymus capitatus), tea tree (Melaleuca alternifolia) and thyme (Thymus vulgaris) essential oils, was investigated against 29 Gram-positive bacterial strains isolated from wastewater treatment plants, clinical samples $(n=25)$ and American Type Culture Collection (ATCC) reference strains $(n=4)$. Wild bacterial strains included methicillin-resistant Staphylococcus aureus $(n=16)$ and vancomycin-resistant Enterococcus spp. $(\mathrm{n}=9)$. The antimicrobial activity of the selected oils was studied using the broth macrodilution method. The Minimal Inhibitory Concentration (MIC) values for $S$. aureus ranged from 0.06 to $0.5 \%(v / v)$ for origanum oil, 0.06 to $1 \%(v / v)$ for thyme oil, 0.12 to $1 \%(v / v)$ for tea tree oil, 0.25 to $4 \%(v / v)$ for basil oil and 2 to $>4 \%(v / v)$ for chamomile oil. For enterococci the MIC values were significantly higher ranging from 0.25 to $1 \%(v / v), 0.5$ to $2 \%(v / v), 1$ to $4 \%(v / v), 4$ to $>4 \%(v / v)$ and $>4 \%(v / v)$ for the above-mentioned oils, respectively. The main compounds of the tested essential oils were: estragole (Ocimum basilicum), bisabolol and trans-b-farnesene (Matricaria chamomilla), carvacrol and thymol (Thymus capitatus), terpinen-4-ol and p-cymene (Melaleuca alternifolia), thymol, linalool, and p-cymene (Thymus vulgaris). Origanum essential oil yielded the best antimicrobial results followed by thyme, tea tree, and basil oil, while chamomile oil exhibited weak antibacterial properties.
\end{abstract}

Keywords: essential oils; antimicrobial activity; MIC; multi-drug resistant; MRSA; VRE

\section{Introduction}

Medicinal plants have been used, since the Hippocrates era, for healing a wide range of diseases including infectious, systematic and inflammatory diseases [1,2]. In contrast the current antimicrobial drugs are used for the treatment of human and animal infections for just less than a century now [3-5]. 
In addition, the development of drug-resistant pathogens appeared quickly, while the emergence of multi-drug resistant strains has increased exponentially during the recent years [6].

Methicillin-resistant Staphylococcus aureus (MRSA), vancomycin-resistant enterococci (VRE), Streptococcus pneumoniae, Mycobacterium tuberculosis, Enterobacteriaceae producing extended spectrum b-lactamases (ESBLs) and carbapenemases, multidrug-resistant isolates causing severe hospital infections in immunocompromised individuals such as Pseudomonas aeruginosa and Acinetobacter baumannii are increasingly reported from both the human and veterinary medicine practice and the aquatic environment as well [4,7-14].

With the emergence of drug resistance and the shortage of effective therapeutics to treat infectious diseases, medicinal plants attracted the attention of researchers looking for new compounds with potent antimicrobial activity. Recent studies suggest plant-essential oils to be associated with sufficient antimicrobial properties against several foodborne pathogens, indicating good prospective for use in food preservation [15-21]. Moreover, there are published data on their use in farm animals for prophylaxis from infectious diseases and as safer substitutes for the antibiotics used for growth promotion [22-26].

Among the actions targeting to reduce and solve the drug-resistance problem is the search for novel antibiotic substances; hence essential oils and their compounds appear to be encouraging replacements. However, most of the published research in this field concerns either reference bacterial strains or non-pathogenic bacteria. Even though there are a few papers concerning clinical isolates [27-31], there is limited information on the essential oils' effect on drug-resistant strains [32-35]. The goal of the present study was to explore the antibacterial effectiveness against multi-drug resistant Gram-positive bacteria isolated from waste water treatment plants and clinical specimens, of five essential oils, which though being widely used in previously conducted studies, their effectiveness against drug-resistant strains is barely addressed in the relevant bibliography.

\section{Materials and Methods}

\subsection{Microorganisms}

The bacterial strains used in this study were isolates from clinical specimens and hospital raw sewage samples obtained from the strain collection of the Microbiology Department (University of Ioannina, Ioannina, Greece). The clinical isolates were: MRSA ( $n=16$, seven isolates from wound swabs, one isolate from blood culture and eight isolates from hospital raw sewage samples) and VRE $(\mathrm{n}=9$, two E. faecium isolates from wound swabs and seven E. faecalis isolates from hospital raw sewage samples). The strains from the American Type Culture Collection were S. aureus ATCC 29213, S. aureus ATCC 43300, S. epidermidis ATCC 12228, and E. faecalis ATCC 51299.

The isolation of the clinical strains used in the present study was performed according to the routine procedures employed by the Clinical Microbiology Laboratory of the University Hospital of Ioannina. Blood specimen were inoculated directly into Bact/Alert ${ }^{\circledR}$ disposable culture bottles, and incubated in the Bact/Alert ${ }^{\circledR}$ Microbial Detection System (bioMerieux SA, Marcy l'Etoile, France). Wound swabs were cultured in Blood agar, Mannitol salt agar and Bile esculin agar (Oxoid Ltd., Basingstoke, UK) and were incubated at $37^{\circ} \mathrm{C}$ for $24-48 \mathrm{~h}$. VITEK ${ }^{\circledR} 2$ microbial ID/AST testing system (bioMerieux SA, Marcy l'Etoile, France) provided identification and susceptibility results. Raw sewage samples were concentrated using the filtration technique onto $0.45-\mu \mathrm{m}$ pore size filter membranes (Merck, Darmstadt, Germany) and placed onto the surface of Mannitol salt agar and Bile esculin media, (Oxoid Ltd., Basingstoke, UK). The plates were incubated aerobically for $48 \mathrm{~h}$ at $37^{\circ} \mathrm{C}$. The identification of isolated species was determined using the API Staph and API 20 STREP identification systems (bioMerieux SA, Marcy l'Etoile, France). The susceptibility tests were carried out using the agar diffusion method and E-test (bioMerieux SA, Marcy l'Etoile, France) following the Clinical and Laboratory Standards Institute (CLSI) guidelines [36]. Susceptibility to the following antibiotics was 
tested: ampicillin, cefoxitin, ciprofloxacin, clindamycin, erythromycin, gentamicin, linezolid, penicillin G, quinupristin/dalfopristin, teicoplanin, tetracycline and vancomycin.

\subsection{Essential Oils}

The following five essential oils were supplied by Sigma-Aldrich Co (Germany): Basil oil (FCC, comoric type, W211907, Ocimum basilicum L., Lamiaceae), Chamomile blue oil (W227307, Matricaria chamomilla L., Asteraceae), Origanum oil (FCC, W282812, Thymus capitatus L., Labiatae), Tea tree oil (W390208, Melaleuca alternifolia, Myrtaceae), Thyme oil-white (FCC, Kosher, W306509, Thymus vulgaris L., Lamiaceae). Since the supplier provided no data about the chemical analysis of these essential oils, a Gas Chromatography-Mass Spectrometry method (GC/MS-QP5000 Shimadzu, Kyoto, Japan) was used as previously reported [35]. Chromatographic conditions and major identified components of the studied essential oils are shown in Table 1.

Table 1. Chromatographic conditions and major identified components of the studied essential oils.

\begin{tabular}{|c|c|}
\hline \multicolumn{2}{|c|}{ GC-17A Gas Chromatograph with GCMS-QP5000 } \\
\hline Column: & $\begin{array}{c}\text { DB-5-MS, } 30 \times 0.32 \mathrm{~mm}, 0.25 \mu \mathrm{m} \text {, containing } 5 \% \\
\text { phenyl-methylpolysiloxane }\end{array}$ \\
\hline Oven: & $\begin{array}{c}55^{\circ} \mathrm{C}, 5^{\circ} \mathrm{C} / \mathrm{min} \text { to } 200{ }^{\circ} \mathrm{C}, 1^{\circ} \mathrm{C} / \mathrm{min} \text { to } 210(2 \mathrm{~min}), 20^{\circ} \mathrm{C} / \mathrm{min} \text { to } \\
270^{\circ} \mathrm{C}(3 \mathrm{~min})\end{array}$ \\
\hline Injector: & $240^{\circ} \mathrm{C}($ splitless mode $)$ \\
\hline Ion source: & $240^{\circ} \mathrm{C}$ \\
\hline Interface: & $290{ }^{\circ} \mathrm{C}$ \\
\hline Scan range: & $m / z 50-450($ full scan $70 \mathrm{eV})$ \\
\hline Carrier gas: & Helium $1.5 \mathrm{~mL} / \mathrm{min}$ \\
\hline \multicolumn{2}{|r|}{ Major Identified Components } \\
\hline Basil oil & estragole \\
\hline Chamomile blue oil & bisabolol and trans-b-farnesene \\
\hline Origanum oil & carvacrol and thymol \\
\hline Tea tree oil & terpinen-4-ol and p-cymene \\
\hline Thyme oil & thymol, p-cymene, and linalool \\
\hline
\end{tabular}

\subsection{Microbiological Assays}

Broth macrodilution assays were performed to determine the Minimal Inhibitory Concentration (MIC) and the Minimal Bactericidal Concentration (MBC) for the essential oils according to the CLSI protocol [36] with minor modifications as previously described [35]. Two-fold serial dilutions of each oil were prepared in Mueller-Hinton broth (MHB, Oxoid Ltd., Basingstoke, UK), with a concentration range of $4 \%(v / v)$ to $0.016 \%(v / v)$. Tween 20 (Thermo Fisher Scientific, Waltham, MA, USA) was used as a solubilizer at a concentration of $0.5 \%(v / v)$. Bacterial inoculum measured by DEN-1 densitometer (Grant Ltd., Cambridgeshire, UK) at a turbidity of $0.5 \mathrm{McFarland}\left(1-1.5 \times 10^{8} \mathrm{cfu} / \mathrm{mL}\right)$, was transferred into MHB to obtain a bacterial count of $5 \times 10^{5} \mathrm{cfu} / \mathrm{mL}$. After a $24 \mathrm{~h}$ incubation at $37^{\circ} \mathrm{C}$ aerobically, an appropriate amount of $10 \mu \mathrm{L}$ was plated onto Mueller-Hinton agar (MHA, Oxoid Ltd., Basingstoke, UK) and incubated under the aforementioned conditions. Viable counts method was used for determination of MIC and MBC values. The MIC is defined as the lowest concentration of an antimicrobial agent that prevents visible growth of a microorganism in an agar or broth dilution susceptibility test. The MBC is identified by determining the lowest concentration of antibacterial agent that reduces the viability of the initial bacterial inoculum by a pre-determined reduction such as $\geq 99.9 \%$ [37-39].

Time-kill kinetics were performed by exposing the tested microorganisms to the two-fold serial concentrations of each essential oil, ranging from $0.063 \%$ to $4 \%(v / v)$ and assessed by viable counts procedure [39]. At $0,1,3,6,8,12,24$ and $48 \mathrm{~h}$ of the dilutions' incubation, $10-\mu \mathrm{L}$ amount of each tube was plated onto duplicate plates of MHA and after $24 \mathrm{~h}$ of incubation at $37^{\circ} \mathrm{C}$, plates were checked for 
visible bacterial growth. Experiments were performed in triplicate and viable counts (cfu/mL) plotted in logarithmic phase in relation to time.

\subsection{Statistical Analysis}

SPSS Statistics V22.0 was used for statistical analysis (IBM Corp., Armonk, NY, USA).

\section{Results}

The antimicrobial susceptibility of the tested isolates is presented in Table 2. Both MRSA and VRE were identified as multidrug-resistant (resistance to 3 or more antibiotics classes tested).

Table 2. Antimicrobial resistance (\%) of the strains used in this study.

\begin{tabular}{ccc}
\hline Antibiotics $\ddagger$ /Bacteria & S. aureus $\mathbf{( n = 1 6 )}$ & Enterococcus spp. (n = 9) \\
\hline PEN & $16(100 \%)$ & $9(100 \%)$ \\
AMP & - & $9(100 \%)$ \\
VAN & $3(18.7 \%)$ & $9(100 \%)$ \\
TEC & $4(25 \%)$ & $9(100 \%)$ \\
ERY & $11(68.7 \%)$ & - \\
CC & $11(68.7 \%)$ & - \\
GEN & $4(25 \%)$ & - \\
FOX & $16(100 \%)$ & - \\
CIP & $11(68.7 \%)$ & $7(77.7 \%)$ \\
QD & $4(25 \%)$ & $9(100 \%)$ \\
LZD & - & $6(66.6 \%)$ \\
TET & - & $5(55.5 \%)$ \\
\hline
\end{tabular}

$\ddagger$ PEN, penicillin G; AMP, ampicillin; VAN, vancomycin; TEC, teicoplanin; ERY, erythromycin; CC, clindamycin; GEN, gentamicin; FOX, cefoxitin; CIP, ciprofloxacin; QD, quinupristin/dalfopristin; LZD, linezolid; TET, tetracycline.

MIC values of selected essential oils against MRSA, VRE and ATCC strains are presented in Figure 1. Origanum, thyme, tea tree and basil oils demonstrated antibacterial activity, while MIC values were higher on the wild MRSA isolates than on the reference strains S. aureus ATCC 29213, S. aureus ATCC 43300 and S. epidermidis ATCC 12228 as well. In general, chamomile oil demonstrated no antibacterial action. The only exception was one sensitive MRSA strain in which both low bacteriostatic $(\mathrm{MIC}=2 \% v / v)$ and bactericidal $(\mathrm{MBC}=2 \% v / v)$ efficacy was occurred (Figure 1A). Origanum, thyme, and tea tree oils demonstrated great antimicrobial activity against enterococci, while basil and chamomile oils presented weak and no antimicrobial properties, respectively (Figure 1B).

The range of MIC and MBC values of the tested essential oils against the selected isolates are presented in Table 3. The mean values of the MICs \pm SD $(\% v / v)$ reported for MRSA were $0.25 \pm$ 0.14 for origanum oil, $0.41 \pm 0.27$ for thyme oil, $0.56 \pm 0.30$ for tea tree oil, and $1.42 \pm 1.43$ for basil oil. Regarding enterococci, origanum oil demonstrated the most significant antimicrobial activity $(0.58 \pm 0.28)$, followed by thyme oil $(1.22 \pm 0.60)$ and tea tree oil $(2 \pm 1.22)$. 

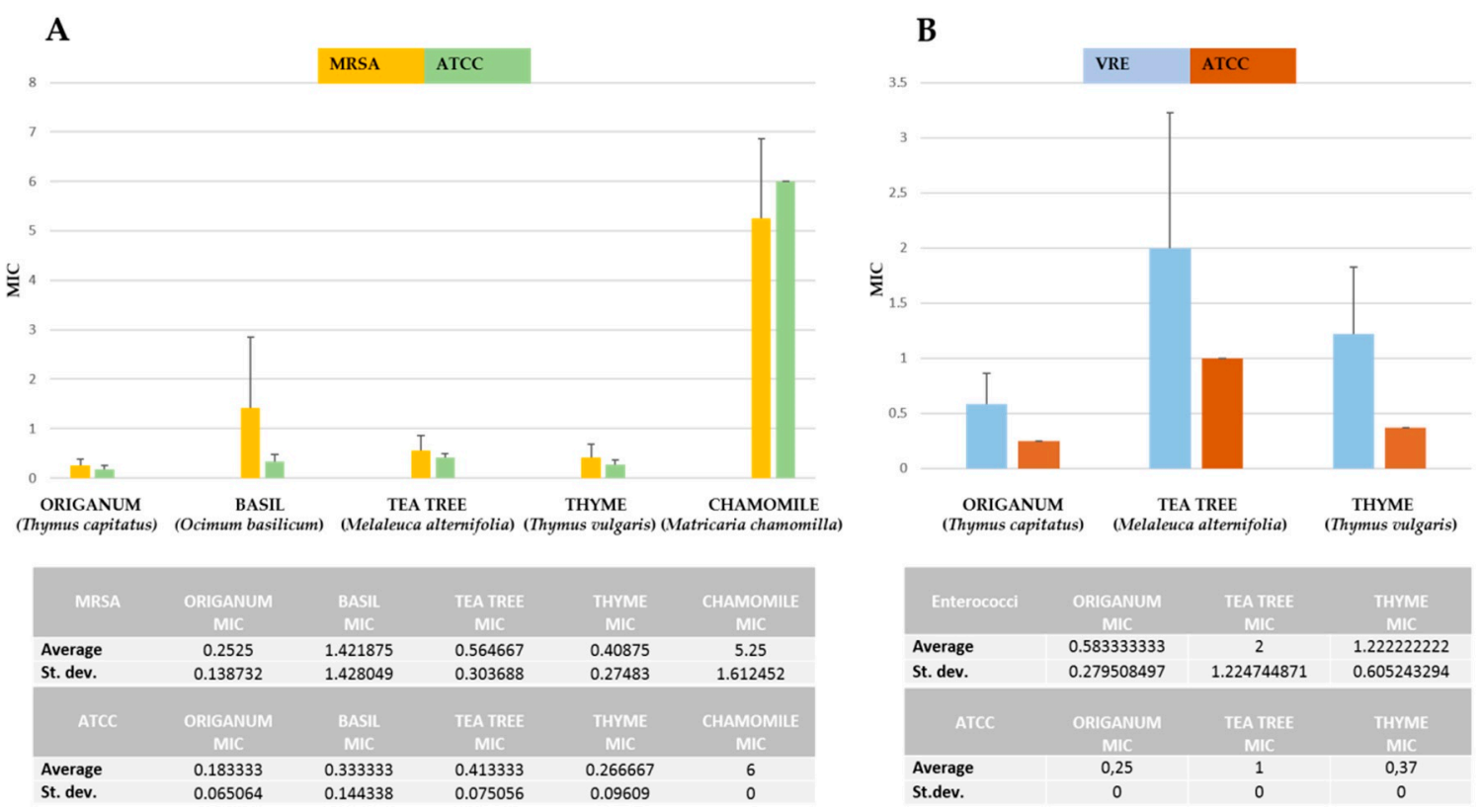

Figure 1. Comparison of MIC values of selected essential oils against wild and ATCC staphylococci (A), wild and ATCC enterococci (B).

Table 3. Range of Minimal Inhibitory Concentration (MIC) and the Minimal Bactericidal Concentration $(\mathrm{MBC})$ values $\%(v / v)$ of selected essential oils against the tested bacteria. MRSA: methicillin-resistant Staphylococcus aureus; VRE: vancomycin-resistant enterococci.

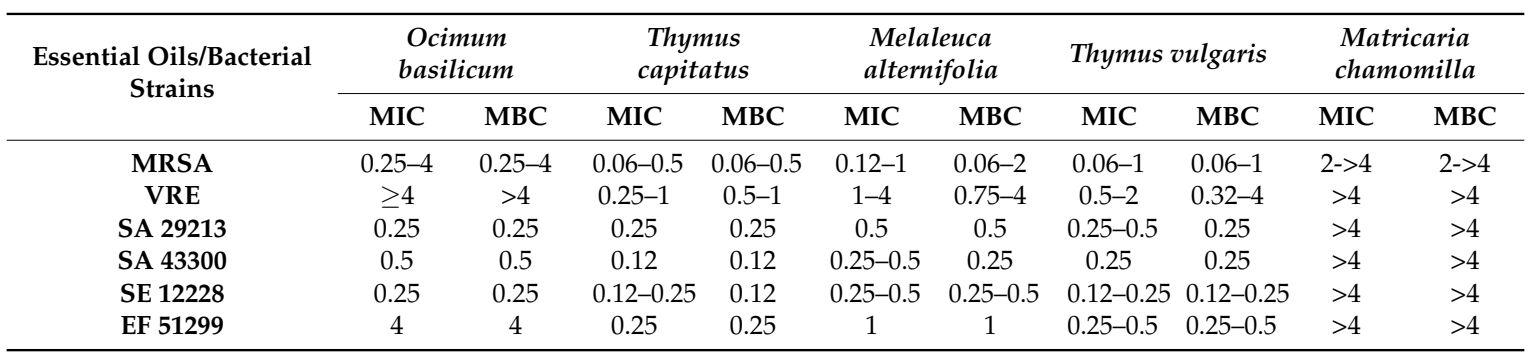

In Figures 2 and 3 the time-kill assays of each essential oil at concentrations ranging from $0.125 \%$ up to $4 \%(v / v)$ against two of the tested clinical isolates (one VRE and one MRSA) are presented. In these two assays, in contrast to the majority of the tested bacteria, the presented VRE isolate (VRE no. 2) exhibited bactericidal response to tea tree and thyme oils at $1 \%(v / v)$ and $0.5 \%(v / v)$ concentrations respectively at $48 \mathrm{~h}$, while the total reduction of viable cells was achieved at higher concentrations at $24 \mathrm{~h}$ (Figure 2). However, the activity of the afore-mentioned oils was reduced at $48 \mathrm{~h}$ on three clinical MRSA isolates and the bactericidal values were one dilution higher than the displayed values at $24 \mathrm{~h}$. Figure 3 presents an example of one clinical MRSA strain (MRSA no. 4) isolated from wound swab, which demonstrated bactericidal response at $1 \%(v / v)$ and $2 \%(v / v)$ to tea tree oil and at $0.12 \%(v / v)$ and $0.25 \%(v / v)$ to thyme oil, after $24 \mathrm{~h}$ and $48 \mathrm{~h}$ of incubation, respectively. 

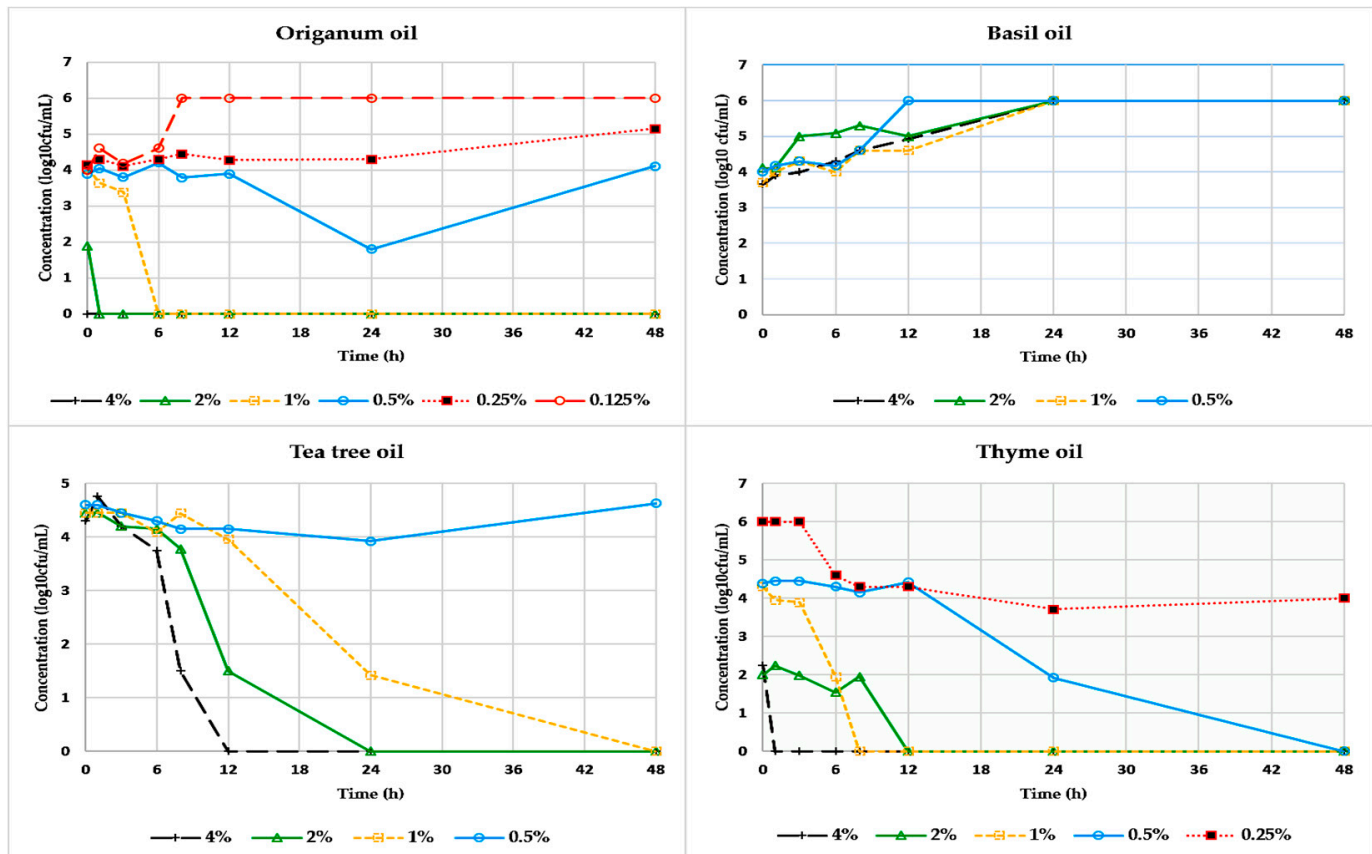

Figure 2. Time-kill kinetics for origanum oil, basil oil, tea tree oil, and thyme oil on a vancomycin resistant E. faecium (VRE no. 2) clinical isolate (isolated from wound swab).

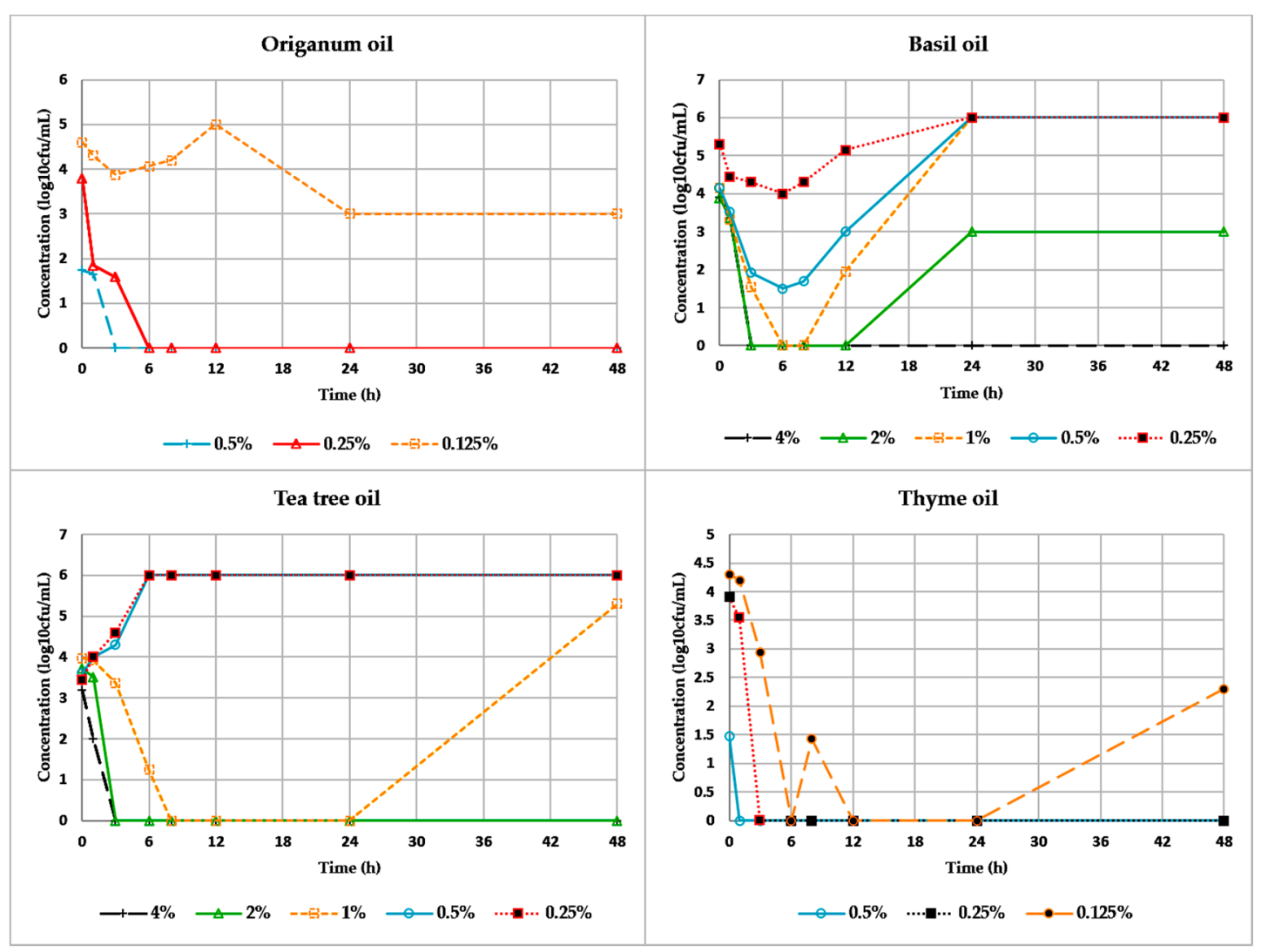

Figure 3. Time-kill kinetics for origanum oil, basil oil, tea tree oil, and thyme oil on the MRSA no. 4 clinical isolate (isolated from wound swab).

\section{Discussion}

The emergence of resistant bacteria is of imperative significance for public health safety [40]. The observed evolution of drug resistance is the end-result of long term selective pressure applied to 
bacteria due to inconsiderate exploitation of the drug use. The appearance of drug-resistance leads to decrease of the existing therapeutic options thus implying the urgency for the development of new antimicrobials [35]. For centuries it has been well acknowledged the potential of medicinal plants to produce a wide range of phytochemicals, mostly alkaloids, phenolic compounds, polyacetylenes and polypeptides $[2,35,41]$. In particular, essential oils have been studied for antimicrobial properties against various non-pathogenic microorganisms and to a lesser extent against pathogenic microorganisms. Although their activity against bacteria of the same genera and species appears to be comparable, yet drug-resistant clinical isolates may show different response from the usually used reference strains $[42,43]$. Therefore, to better document the antimicrobial performance of essential oils, it is essential to test drug-resistant isolates from different sources (diseased humans, animals, food, water, environment) in order to have a realistic indication of their antimicrobial effect [35]. In the available literature the majority of the published papers employ reference strains, or non-pathogenic strains and scarcely multi-drug resistant isolates. This variety in the used strains and the diversity of the employed methods produces variable findings and the comparative assessment of the published results is difficult.

Regarding the essential oils and the bacterial isolates employed in the present study the literature search revealed only a few publications relating to drug-resistant clinical strains. However, there are variations in the methodological approach that make any comparison of their findings with our results rather inaccurate. A study on the antimicrobial activity of origanum (Origanum vulgare) and basil (Ocimum basilicum) oils against clinical strains of S. aureus showed that only origanum essential oil was effective and concluded that wild clinical strains are less sensitive to essential oils compared to prototype strains but no data on the strain susceptibility are presented [29]. Nostro et al. (2004) using the agar diffusion method, have evaluated the MIC values of origanum oil (O. vulgare, thymol chemotype) at a range of 0.063 to $0.125 \%(v / v)$ against methicillin-resistant $S$. aureus and methicillin-resistant S. epidermidis strains and at $0.125 \%(v / v)$ against $S$. aureus ATCC 25923, S. aureus ATCC 43300 and S. epidermidis ATCC 12228 [44]. Although Nostro et al., have used the same ATCC strains which we used in our study too, the methodological approach is different justifying the observed discrepancies (Table 3). Preuss et al. (2005) report that the MIC of S. aureus ATCC 33591 to origanum oil, determined by a broth macrodilution method, was $0.5 \%(v / v)$, but here again this is a different reference strain [45]. Hammer et al. (1999), using the broth microdilution method, evaluated the MIC of tea tree oil, basil oil, origanum oil, and thyme oil against $S$. aureus National Collection of Type Cultures (NCTC) 6571 at concentrations $0.5 \%, 2 \%, 0.12 \%$ and $0.25 \%(v / v)$ respectively [46], while Carson et al. (2002) report that the MIC and MBC of tea tree oil against S. aureus ATCC 9144 were determined at concentrations $0.25 \%$ and $0.5 \%(v / v)$ respectively [47], but a different reference strain was used and no clinical drug-resistant isolates were tested. Mann and Markham (1997) using the broth microdilution method, report the MIC for tea tree oil against MRSA at concentration of $0.08 \%$ $(v / v)$, which was less than that in our study, however the findings cannot be compared because no data from the sensitivity tests are provided [48]. Hammer et al. (1996) report the tea tree oil MIC and MBC against $S$. aureus to be $0.12-0.5 \%(v / v)$ and $0.25-2 \%(v / v)$ respectively [37], whereas Nelson (2000) reports that the tea tree oil MIC against MRSA was $0.25 \%(v / v)$ without providing the sensitivity test details [49]. Both studies, presented similar results with our findings (Table 3), but again there are differences in the methodological approaches.

In the present study the MIC values reported for origanum oil, thyme oil and tea tree oil against S. aureus (MRSA, reference strains) in general are not different from those reported by other researchers, but still there is the methodological diversity difference. Concerning the reported MIC values for basil oil in our study they were much different denoting much less effective antimicrobial activity against drug-resistant clinical isolates. In the aforementioned literature the methods used for the determination of the antimicrobial activity of the essential oils, included agar well diffusion assays, paper disk diffusion assays, agar dilution assays and broth microdilution and macrodilution methods. Even surfactants such as Tween 20 (polyoxyethylene 2-sorbitan monolaurate) or Tween 80 (polysorbate 
80) are variable in different papers, even though they are used only to enhance oil solubility without contributing to the antimicrobial activity. Regarding the employed essential oils, even when identical names are reported it is uncertain whether their main constituents are exactly the same. Several factors such as the plant growth stage, environmental and ecological conditions, harvesting and processing conditions, and plant endogenous factors can affect the composition of the extracted essential oil [39].

Nevertheless, our results like most of the findings reported by other researchers indicate that essential oils are likely to act as alternative antimicrobial agents against some multi-drug resistant Gram-positive isolates. It has to be emphasized that Gram-positive bacteria are not considered to be as resistant as the Gram-negatives [50]. To a large extent this trait is attributed to differences in their cell wall structure which is less complex in Gram-positives than in Gram-negatives, allowing the penetration of antimicrobial compounds, such as the phenolic compounds (e.g., thymol, carvacrol, eugenol) of the essential oils [18,51]. The cell wall of the Gram-positive bacteria permits hydrophobic molecules to get into the cells and act on the cell wall and the cytoplasm. Apparently, the potential antimicrobial activity of the essential oils' compounds derives from their ability to disrupt the bacterial cell wall and the cytoplasmic membrane, consequently leading to cell lysis and leakage of intracellular compounds [52]. Taking into consideration that an intact cell wall is vital for the bacterium survival, any changes in the permeability of the cell wall and cytoplasmic membrane affect the bacterial propagation. In the presence of antibacterial compounds in their environment, bacteria are forced to alter the synthesis of fatty acids and membrane proteins in order to survive by modifying the permeability of their cell wall $[53,54]$. Essential oils particularly those rich in phenolics have the ability to penetrate the phospholipids layer of the bacterial cell wall, bind to proteins and block their functions. Existing data on the essential oils antimicrobial activity show that their potency depends on several biochemical and structural mechanisms that take place at various sites of the bacterial cell and more research in this direction is needed to explore thoroughly the antimicrobial potential of plant essential oils.

Author Contributions: H.S.; Conceptualization, Methodology, Investigation, Visualization, Writing-Original Draft Preparation, Writing-Review \& Editing, V.E.; Methodology, Software, Data Curation, Formal Analysis, P.G.; Methodology, Data Curation, Formal Analysis, P.B.; Methodology, Data Curation, Software, V.A.S.; GC-MS Methodology, S.P.; Formal Analysis, G.M.; Methodology, A.I.; Methodology, C.P.; Conceptualization, Visualization, Validation, Writing-Review \& Editing, Supervision.

Funding: This research was financially supported by the HERAKLEITOS Project $61 / 1733 / 7$, funded by the EPEAEK Administration Office of the Greek Ministry of Education.

Conflicts of Interest: The authors declare no conflict of interest.

\section{References}

1. Gurib-Fakim, A. Medicinal Plants: Traditions of yesterday and drugs of tomorrow. Mol. Aspects Med. 2006, 27, 1-93. [CrossRef] [PubMed]

2. Sakkas, H.; Papadopoulou, C. Antimicrobial activity of Basil, Oregano and Thyme essential oils. J. Microbiol. Biotechnol. 2017, 27, 429-438. [CrossRef] [PubMed]

3. Teuber, M. Veterinary use and antibiotic resistance. Curr. Opin. Microbiol. 2001, 4, 493-499. [CrossRef]

4. Levy, S.; Marshall, B. Antimicrobial resistance worldwide: Causes, challenges and responses. Nat. Med. 2004, 10, 122-129. [CrossRef] [PubMed]

5. Wittekamp, B.H.; Bonten, M.J. Antibiotic prophylaxis in the era of multidrug-resistant bacteria. Expert Opin. Investig. Drugs 2012, 21, 767-772. [CrossRef] [PubMed]

6. Michael, C.A.; Franks, A.E.; Labbate, M. The antimicrobial resistance crisis: Management through gene monitoring. Open Biol. 2016, 6, 160236. [CrossRef] [PubMed]

7. Papadopoulou, C.; Dimitriou, D.; Levidiotou, S.; Panagiou, A.; Gessouli, H.; Antoniades, G. Bacterial strains isolated from eggs and their resistance to currently used antibiotics: Is there a health hazard for the consumers? Comp. Immun. Microbiol. Infect. Dis. 1997, 20, 35-40. [CrossRef]

8. Rodríquez-Baño, J.; Pascual, A. Clinical significance of extended-spectrum beta-lactamases. Expert. Rev. Anti Infect. Ther. 2008, 6, 671-683. [CrossRef] [PubMed] 
9. Shorr, A.E. Review of studies of the impact on Gram-negative bacterial resistance on outcomes in the intensive care unit. Crit. Care Med. 2009, 37, 1463-1469. [CrossRef] [PubMed]

10. Gousia, P.; Economou, V.; Sakkas, H.; Leveidiotou, S.; Papadopoulou, C. Antimicrobial resistance of major foodborne pathogens from major meat products. Foodborne Pathog. Dis. 2010, 8, 27-38. [CrossRef] [PubMed]

11. Wieler, L.H.; Ewers, C.; Guenther, S.; Walther, B.; Lübke-Becker, A. Methicillin-resistant staphylococci (MRS) and extended-spectrum beta-lactamases (ESBL)-producing Enterobacteriaceae in companion animals: Nosocomial infections as one reason for the rising prevalence of these potential zoonotic pathogens in clinical samples. Int. J. Med. Microbiol. 2011, 301, 635-641. [PubMed]

12. Coenen, S. Infectious diseases in primary care; managing the interface between the person and the community. Eur. J. Gen. Pract. 2012, 18, 117-121. [CrossRef] [PubMed]

13. Economou, V.; Gousia, P.; Kansouzidou, A.; Sakkas, H.; Karanis, P.; Papadopoulou, C. Prevalence, antimicrobial resistance and relation to indicator and pathogenic microorganisms of Salmonella enterica isolated from surface waters within an agricultural landscape. Int. J. Hyg. Environ. Health 2013, 216, 435-444. [CrossRef] [PubMed]

14. Gousia, P.; Economou, V.; Bozidis, P.; Papadopoulou, C. Vancomycin-resistance phenotypes, Vancomycin-resistance genes, and resistance to antibiotics of Enterococci isolated from food of animal origin. Foodborne Pathog. Dis. 2015, 12. [CrossRef] [PubMed]

15. Prabuseenivasan, S.; Jayakumar, M.; Ignacimuthu, S. In vitro antibacterial activity of some plant essential oils. BMC Complement. Altern. Med. 2006, 6, 39. [CrossRef] [PubMed]

16. Dadalioglu, I.; Evrendilek, G.A. Chemical compositions and antibacterial effects of essential oils of Turkish oregano (Origanum minutiflorum), bay Laurel (Laurus nobilis), Spanish levander (Lavandula stoechas L.), and fennel (Foeniculum vulgare) on common foodborne pathogens. J. Agric. Food Chem. 2004, 52, 8255-8260. [CrossRef] [PubMed]

17. Solomakos, N.; Govaris, A.; Koidis, P.; Botsoglou, N. Antimicrobial effect of thyme essential oil, nisin, and their combination against Listeria monocytogenes in minced beef during refrigerated storage. Food Microbiol. 2008, 25, 120-127. [CrossRef] [PubMed]

18. Tiwari, B.K.; Valdramidis, V.P.; O’Donnell, C.P.; Muthukumarappan, K.; Bourke, P.; Cullen, P.J. Application of natural antimicrobials for food preservation. J. Agric. Food Chem. 2009, 57, 5987-6000. [CrossRef] [PubMed]

19. Fratianni, F.; De Martino, L.; Melone, A.; De Feo, V.; Coppola, R.; Nazzaro, F. Preservation of chicken breast meat treated with thyme and balm essential oils. J. Food Sci. 2010, 75, M528-M535. [CrossRef] [PubMed]

20. Hyldgaard, M.; Mygind, T.; Meyer, R.L. Essential oils in food preservation: Mode of action, synergies and interactions with food matrix components. Front. Microbiol. 2012, 3, 1-24. [CrossRef] [PubMed]

21. Yossa, N.; Patel, J.; Millner, P.; Lo, Y.M. Essential oils reduce Escherichia coli O157:H7 and Salmonella on spinach leaves. J. Food Prot. 2012, 75, 488-496. [CrossRef] [PubMed]

22. Penalver, P.; Huerta, B.; Borge, C.; Astorga, R.; Romero, R.; Perea, A. Antimicrobial activity of five essential oils against origin strains of the Enterobacteriaceae family. APMIS 2005, 113, 1-6. [CrossRef] [PubMed]

23. Windisch, W.; Schedle, K.; Plitzner, C.; Kroismayr, A. Use of phytogenic products as feed additives for swine and poultry. J. Anim. Sci. 2008, 86, E140-E148. [CrossRef] [PubMed]

24. Huyghebaert, G.; Ducatelle, R.; Van Immerseel, F. An update on alternatives to antimicrobial growth promoters for broilers. Vet. J. 2011, 187, 182-188. [CrossRef] [PubMed]

25. Maenner, K.; Vahjen, W.; Simon, O. Studies of the effects of essential-oil-based feed additives on performance, ileal nutrient digestibility and selected bacterial groups in the gastrointestinal tract of piglets. J. Anim. Sci. 2011, 89, 2106-2112. [CrossRef] [PubMed]

26. Doyle, M.P.; Erickson, M.C. Opportunities for mitigating pathogen contamination during on-farm food production. Int. J. Food Microbiol. 2012, 152, 54-74. [CrossRef] [PubMed]

27. Banes-Marshall, L.; Cawley, P.; Phillips, C.A. In vitro activity of Melaleuca alternifolia (tea tree) oil against bacterial and Candida spp. Isolates from clinical specimens. Br. J. Biomed. Sci. 2001, 58, 139-145. [PubMed]

28. Warnke, H.; Becker, S.T.; Podschun, R.; Sivananthan, S.; Springer, I.N.; Russo, P.A.J.; Wiltfang, J.; Fickenscher, H.; Sherry, E. The battle against multi-resistant strains: Renaissance of antimicrobial essential oils as a promising force to fight hospital-acquired infections. J. Craniomaxillofac. Surg. 2009, 37, $392-397$. [CrossRef] [PubMed] 
29. Alexopoulos, A.; Kimbaris, A.C.; Plessas, S.; Mantzourani, I.; Theodoridou, I.; Stavropoulou, E.; Polissiou, M.G.; Bezirtzoglou, E. Antibacterial activities of essential oils from eight Greek aromatic plants against clinical isolates of Staphylococcus aureus. Anaerobe 2011, 17, 399-402. [CrossRef] [PubMed]

30. Sienkiewicz, M.; Łysakowska, M.; Ciećwierz, J.; Denys, P.; Kowalczyk, E. Antibacterial activity of thyme and lavender essential oils. Med. Chem. 2011, 7, 674-689. [CrossRef] [PubMed]

31. Crandall, P.G.; Ricke, S.C.; O’Bryan, C.A.; Parrish, N.M. In vitro effects of citrus oils against Mycobacterium turberculosis and non-tuberculous Mycobacteria of clinical importance. J. Environ. Sci. Health B 2012, 47, 736-741. [CrossRef] [PubMed]

32. Ferrini, A.M.; Mannoni, V.; Aureli, P.; Salvatore, G.; Piccirilli, E.; Ceddia, T.; Pontieri, E.; Sessa, R.; Oliva, B. Melaleuca alternifolia essential oil possesses potent anti-staphylococcal activity extended to strains resistant to antibiotics. Int. J. Immunopathol. Pharmacol. 2006, 19, 539-544. [CrossRef] [PubMed]

33. Ravishankar, S.; Zhu, L.; Law, B.; Joens, L.; Friedman, M. Plant-derived compounds inanctivate antibiotic-resistant Campylobacter jejuni strains. J. Food Prot. 2008, 71, 1145-1149. [CrossRef] [PubMed]

34. Tohidpour, A.; Sattari, M.; Omidbaigi, R.; Yadegar, A.; Nazemi, J. Antibacterial effect of essential oils from two medicinal plants against Methicillin-resistant Staphylococcus aureus (MRSA). Phytomedicine 2010, 17, 142-145. [CrossRef] [PubMed]

35. Sakkas, H.; Gousia, P.; Economou, V.; Sakkas, V.; Petsios, S.; Papadopoulou, C. In vitro antimicrobial activity of five essential oils against multi-drug resistant Gram-negative clinical isolates. J. Intercult. Ethnopharmacol. 2016, 5, 212-218. [CrossRef] [PubMed]

36. Clinical and Laboratory Standards Institute (CLSI). Performance Standards for Antimicrobial Susceptibility Testing, 27th ed.; CLSI: Wayne, PA, USA, 2017.

37. Hammer, K.A.; Carson, C.F.; Riley, T.V. Susceptibility of transient and commensal skin flora to the essential oil of Melaleuca alternifolia (tea tree oil). Am. J. Infect. Control 1996, 24, 186-189. [CrossRef]

38. Clinical and Laboratory Standards Institute (CLSI). Methods for Dilution Antimicrobial Susceptibility Tests for Bacteria that Grow Aerobically, 9th ed.; Approved Standard; CLSI: Wayne, PA, USA, 2012.

39. Moreira, M.R.; Ponce, A.G.; Del Valle, C.E.; Roura, S.I. Inhibitory parameters of essential oils to reduce a foodborne pathogen. LWT 2005, 38, 565-570. [CrossRef]

40. Economou, V.; Gousia, P. Agriculture and food animals as a source of antimicrobial-resistant bacteria. Infect. Drug. Resist. 2015, 1, 49-51. [CrossRef] [PubMed]

41. Cowan, M.M. Plant Products as Antimicrobial Agents. Clin. Microbiol. Rev. 1999, 12, 564-582. [CrossRef] [PubMed]

42. Canillac, N.; Mourey, A. Effects of several environmental factors on the anti-Listeria monocytogenes activity of an essential oil of Picea excelsa. Int. J. Food Microbiol. 2004, 92, 95-103. [CrossRef] [PubMed]

43. Chorianopoulos, N.G.; Evergetis, E.T.; Aligiannis, N.; Mitakou, S.; Nychas, G.J.E.; Haroutian, S.A. Correlation between chemical composition of Greek essential oils and their antibacterial activity against food-borne pathogens. Nat. Prod. Commun. 2007, 2, 419-426.

44. Nostro, A.; Blanco, A.; Cannatelli, M.; Enea, V.; Flamini, G.; Morelli, I.; Roccaro-Sudano, A.; Alonzo, V. Susceptibility of methicillin-resistant staphylococci to oregano essential oil, carvacrol and thymol. FEMS Microbiol. Lett. 2004, 230, 191-195. [CrossRef]

45. Preuss, H.; Echard, B.; Enig, M.; Brook, I.; Elliot, T. Minimum inhibitory concentrations of herbal essential oils and monolaurin for gram-positive and gram-negative bacteria. Mol. Cell. Biochem. 2005, 272, $29-34$. [CrossRef] [PubMed]

46. Hammer, K.A.; Carson, C.F.; Riley, T.V. Antimicrobial activity of essential oils and other plant extracts. J. Appl. Microbiol. 1999, 86, 985-990. [CrossRef] [PubMed]

47. Carson, C.; Mee, B.; Riley, T. Mechanism of action of Melaleuca alternifolia (Tea Tree) oil on Staphylococcus aureus determined by time-kill, lysis, leakage and salt tolerance assays and electron microscopy. Antimicrob. Agents Chemother. 2002, 46, 1914-1920. [CrossRef] [PubMed]

48. Mann, C.M.; Markham, J.L. A new method for determining the minimum inhibitory concentration of essential oils. J. Appl. Microbiol. 1998, 84, 538-544. [CrossRef] [PubMed]

49. Nelson, R. Selection of resistance to the essential oil of Melaleuca alternifolia in Staphylococcus aureus. J. Antimicrob. Chemother. 2000, 45, 547-551. [CrossRef]

50. Nazzaro, F.; Fratianni, F.; De Martino, L.; Coppola, R.; De Feo, V. Effect of Essential Oils on Pathogenic Bacteria. Pharmaceuticals 2013, 6, 1451-1474. [CrossRef] [PubMed] 
51. Trombetta, D.; Castelli, F.; Sarpietro, M.G.; Venuti, V.; Cristani, M.; Daniele, C.; Saija, A.; Mazzanti, G.; Bisignano, G. Mechanisms of antibacterial action of three monoterpenes. Antimicrob. Agents Chemother. 2005, 49, 2474-2478. [CrossRef] [PubMed]

52. Lopez Romero, J.; González-Rios, H.; Borges, A.; Simões, M. Antibacterial effects and mode of action of selected essential oils components against Escherichia coli and Staphylococcus aureus. J. Evid. Based Complement. Altern. Med. 2015. [CrossRef] [PubMed]

53. Burt, S.A.; Reinders, R.D. Antibacterial activity of selected plant essential oils against Escherichia coli O157:H7. Lett. Appl. Microbiol. 2003, 36, 162-167. [CrossRef] [PubMed]

54. Mrozik, A.; Piotrowska-Seget, Z.; Labuzek, S. Changes in whole cell-derived fatty acids induced by naphthalene in bacteria from genus Pseudomonas. Microbiol. Res. 2004, 1, 87-95. [CrossRef] [PubMed]

2018 by the authors. Licensee MDPI, Basel, Switzerland. This article is an open access article distributed under the terms and conditions of the Creative Commons Attribution (CC BY) license (http:/ / creativecommons.org/licenses/by/4.0/). 